\title{
Four-year survey of dissolved/dispersed petroleum hydrocarbons on surface waters of Admiralty Bay, King George Island, Antarctica
}

\author{
Márcia Caruso Bícego'; Eliete Zanardi-Lamardo ${ }^{2}$ \& Rolf Roland Weber ${ }^{1}$ \\ Instituto Oceanográfico da Universidade de São Paulo \\ Departamento de Oceanografia Física \\ (Praça do Oceanográfico, 191 Butantã 05508-900, São Paulo, SP, Brasil) \\ marcia@io.usp.br \\ University of Miami \\ ${ }^{2}$ Division of Marine and Atmospheric Chemistry \\ Rosenstiel School of Marine and Atmospheric Science \\ (4600 Rickenbacker Causeway Miami, FL, 33149 USA)
}

- Abstract: Seawater from 8 stations in Admiralty Bay was systematically sampled during the summer of 1994, 1995, 1996 and 1997 and analyzed by spectrofluorimetry to measure dissolved/dispersed petroleum hydrocarbons (DDPHs). The purpose of this study was to detect some temporal and spatial changes in terms of oil contamination of the region. The results indicate low levels of oil pollution with relatively high concentrations near the research stations located in the study area. During the summers of 1995 and 1996 the average concentrations for individual stations were low and below of $0.50 \mu \mathrm{g} . \mathrm{L}^{-1}$. Summers of 1994 and 1997 had relatively higher average concentrations (up to $1.57 \mu \mathrm{g} . \mathrm{L}^{-1}$ ), mainly in front of Arctowski and Ferraz Research Stations.

- Resumo: Amostras de água na Baía do Almirantado, Península Antártica, foram sistematicamente coletadas em 8 estações durante os verões de 1994 a 1997 onde foram analisados hidrocarbonetos do petróleo dispersos e dissolvidos por espectrofluorescência. O objetivo foi avaliar variações temporais e espaciais em termos de contaminação por óleo na região. Os resultados em geral indicam baixos níveis de poluição embora tenham sido verificadas algumas concentrações relativamente maiores nas proximidades das estações de pesquisa fixadas na região de estudo. Durante os anos de 1995 e 1996 a média das concentrações foram baixas e menores que $0,50 \mu \mathrm{g} . \mathrm{L}^{-1}$ para os pontos individuais. Os verões de 1994 e 1997 tiveram concentrações médias mais elevadas (até 1,57 $\mu \mathrm{g} . \mathrm{L}^{-1}$ ), e os maiores valores foram nas proximidades das estações brasileira e polonesa.

- Descriptors: Petroleum hydrocarbons, Marine pollution, Antarctica, Admiralty Bay, Monitoring programs.

- Descritores: Hidrocarbonetos do petróleo, Poluição marinha, Antártica, Baía do Almirantado, Programas de monitoramento.

Contr: no. 851 do lnst. oceanogr. da Usp. 


\section{Introduction}

The Antarctic continent is a remote and not occupied area but it is not entirely free of environmental impact. Concern about oil pollution in the Antarctic environment has increased in recent years, as the result of the expansion of human activities in that region. Accidental and chronic releases of oil and its derivatives during the supporting activities of scientific bases, added to the presence of tourist vessels are likely sources of contamination. Approximately $90 \times 10^{6}$ L.y $y^{-1}$ of fuels are used in Antarctic in research activities and there are no data for the amount used by fishing and tourist vessels (Cripps \& Shears, 1997). Potential risks can be illustrated by some accidents like the Bahia Paraiso spill in March 1989 (Kennicut et al., 1991).

Cripps (1992) in his review observed that hydrocarbon pollution in Antarctic environment is not a widespread problem but there are localized problems caused by research stations (Lenihan, 1992; Cripps, 1992; Green \& Nichols, 1995) and occasional spills (Kennicutt, et al., 1991). On the other hand a systematic survey with repeated sampling stations has not been carried out in the region. The objective of this study was to assess the influence of the research stations in Admiralty Bay on the hydrocarbons levels.

\section{Area description}

Admiralty Bay is $131 \mathrm{~km}$ wide and one of the biggest bays within the entire South Shetlands Islands. The Brazilian Comandante Ferraz Station was established in the summer of 1984 at the East Coast of the Keler Peninsula and today it is a medium sized research station supplied by 6 generators. The summer population is of about 40 people. Every year the station uses $320,000 \mathrm{~L}$ of Arctic grade diesel oil stored in 17 double-walled steel tanks, which is refilled every summer by ship. The average monthly consumption of about 23 tons of fuel in the diesel generators, poses potential risk of direct hydrocarbons release to the environment. Furthermore, the incinerator and exhaust emissions are sources of polycyclic aromatic hydrocarbons to the local atmosphere. The Polish Research Station of Arctowski is located at Thomas Point and was established in the western Admiralty Bay in 1977. In this station there is a total storage capacity of 1,000,000 L of fuel. The Machu Picchu Peruvian Station was built in 1988 at Crépin Point, Mackellar Inletis and presently is used only for summer operations (COMNAP. 2001).

\section{Methods}

A four-year survey was undertaken on 8 stations of Admiralty Bay (Fig. 1). Samples of sub-surface seawater were taken during 5 days in the summers of 1994 to 1997. The location of the sampling stations was chosen based on a previous study that covered the entire bay (Bicego et al., 1996). This previous study revealed some spots of relatively high petroleum hydrocarbon levels that were related to the areas with more intense boating activities and diesel fuel uses. Dissolved/dispersed petroleum hydrocarbons (DDPHs) were measured by fluorescence spectroscopy according to IOC/UNEP (1984) procedure with modifications in the extraction as proposed by Ehrhardt (1983). There are some methodological limitations for the use of UV fluorescence like the undistinguishable fluorescence characteristics of biosynthesed compounds from oil residues (Ehrhardt \& Knap, 1989). The low fluorescence intensity does not necessarily mean a low concentration of oil residues. It could be a result of the transformation of fluorescent hydrocarbons into less or non-fluorescent oxidation products (Ehrhardt et al., 1992). In addition, the polycyclic aromatic hydrocarbons fluorescence in aqueous solution may be quenched upon association with humic material (Gauthier et al., 1986), and the results presented might be underestimated. Recently. Parlanti et al. (2000) reported that biological activity is one of the major contributors to the fluorescence band observed in marine waters with excitation in the range of 310-320 $\mathrm{nm}$ and emission at 380-400 nm. These excitation/emission wavelengths are close to the pair used in this study (exc/em = $310 / 360 \mathrm{~nm}$ ), indicating that, if substantial, the biological activity of the area could interfere in the presented results. The fluorescence data does not provide any inside of the molecular composition like GC-MS or HPLC techniques do. On the other hand, GC-MS is not a suitable routine technique, especially if it is necessary to quickly analyze a great number of water samples. The GC-MS technique requires high volumes $(100 \mathrm{~L}$ or more) of seawater to analyze in details the composition of the dissolved lipophilic organic fraction (Bícego et al., 1996), limiting the number of samples. In spite of the fluorescence limitations, systematic studies have established the comparability of the results and the general usefulness of the method (Law et al. 1987; Maher, 1983). Despite of all the limitations of the technique, this method is a useful tool in monitoring and verifying tendencies in a particular area before using more sophisticated techniques 


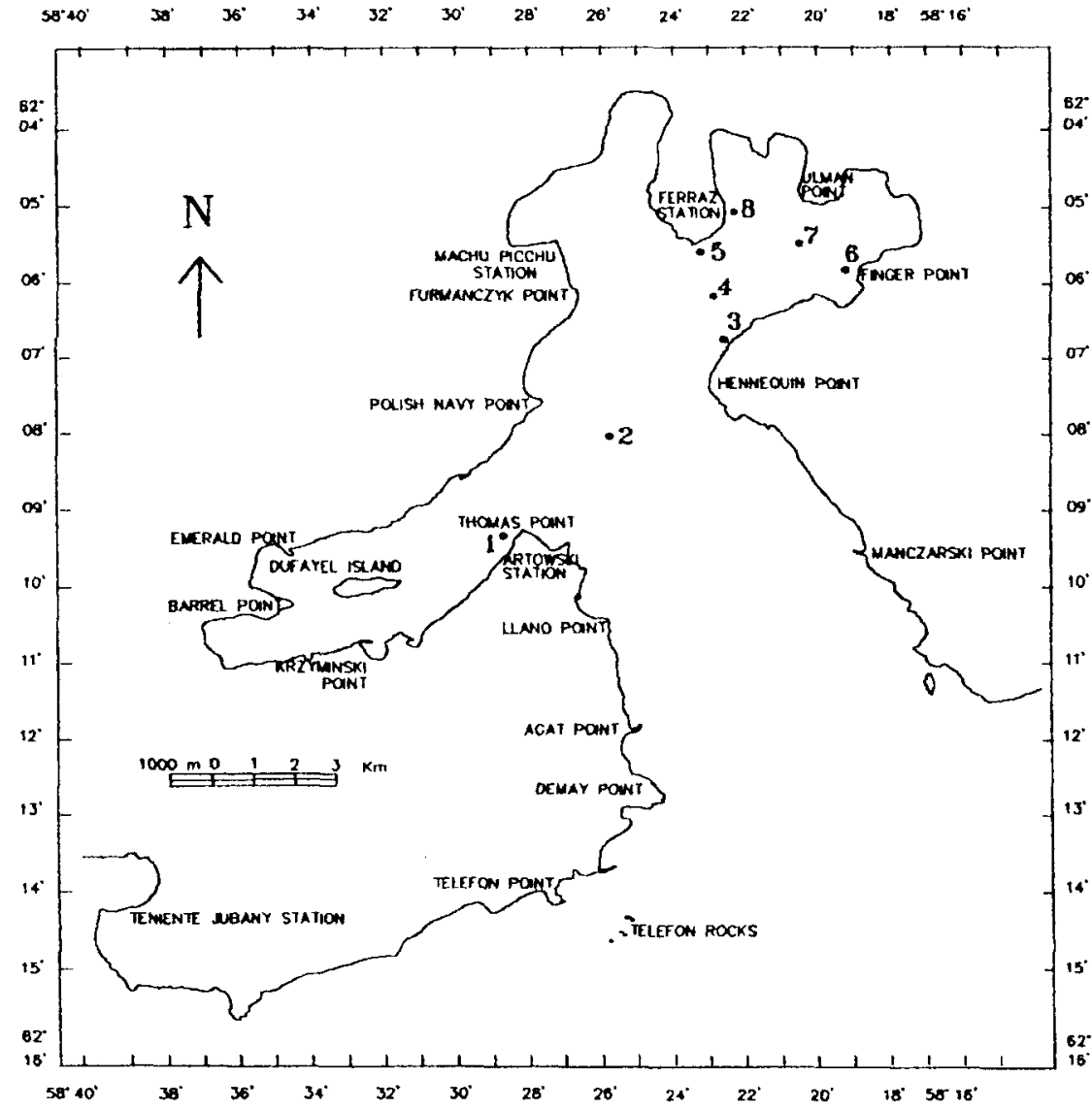

Fig. 1. Sampling Stations of seawater at Admiralty Bay. Antarctic Peninsula.

Subsurface water was sampling at one-meter depth with 4 liter amber glass bottles, fixed to a metal weighed frame, immediately before stopping the boat at the station to avoid contamination. All glassware used during the analysis was meticulous cleaned using dextran $20 \%$, rinsing them with distilled water, ethylic alcohol, and drying them in the oven at $100^{\circ} \mathrm{C}$. Immediately before the use, all glassware were rinsed with n-hexane. All solvents were pesticide grade and the whole procedure was always checked with blanks. Extraction of the water was done with n-hexane, and the extract concentrated to $5 \mathrm{~mL}$. Fluorescence of the samples was measured in a Perkin-Elmer Spectrofluorimeter Model LC 240 using $310 \mathrm{~nm}$ for excitation wavelength and $360 \mathrm{~nm}$ for emission wavelength. The calibration curve was made with an artificially weathered crude oil standard, obtained by distilling Carmópolis crude oil (Brazil) at $110^{\circ} \mathrm{C}$. Samples outside the calibration curve range were diluted with n-hexane to fall in the appropriate range. Average blank was $0.02 \mu \mathrm{g} . \mathrm{L}^{-1}$, and this value was subtracted from all samples. The detection limit (DL) was considered the blank signal plus 3 standard deviation of the blank, which corresponds to $0.07 \mu \mathrm{g}$.
$\mathrm{L}^{-1}$. In order to calculate the average concentration for each station the value of DL $\left(0.07 \mu \mathrm{g} . \mathrm{L}^{-1}\right)$ was considered for samples with concentration below DL (Table 1).

A Principal Component Analysis (PCA) was performed in order to characterize the DDPHs distribution. The variables were previously transformed $(\log x+1)$ to give the best approximation of the nomality. The PCA was done from a correlation matrix with 4 variables (concentration of DDPhs, distance from the Brazilian Research Station, distance from the Polish Research Station, and the sampling years) with 160 observations.

\section{Results and discussion}

DDPHS concentrations from the 8 sampling stations are shown on Table 1. Individual samples varied from below detection limit $(<0.07)$ to 2.94 $\mu g . L^{-1}$ and average concentration for each station for the entire study period ranged from 0.08 to 1.57 $\mu \mathrm{g} . \mathrm{L}^{-1}$ Concentrations were relatively low when 
Table 1. Dissolved/dispersed petroleum hidrocarbons (ug. L. Camopolis oil equivalents) in waters from Admiralty Bay. Antaretic Peninsula, with average and standard deviation (SD).

\begin{tabular}{|c|c|c|c|c|c|c|c|}
\hline Date & 1 & 2 & 3 & 4 & 5 & 6 & 7 \\
\hline \multicolumn{8}{|l|}{1994} \\
\hline 27/jan & 1.08 & 1.22 & 0.46 & 1.81 & 0.33 & 0.36 & 0.61 \\
\hline 28/jan & 0.94 & 1.09 & 0.25 & 0.78 & 1.47 & 0.23 & 0.61 \\
\hline $22 / \mathrm{fev}$ & 1.82 & 1,03 & 0,99 & 0.83 & 1.23 & 0,18 & 0,85 \\
\hline $28 / \mathrm{fev}$ & 1.05 & 0,99 & 1.07 & 0.76 & 0.96 & 0.58 & 0.33 \\
\hline $1 / \mathrm{mar}$ & 2.94 & 0.20 & 1,26 & 0.58 & 1,63 & 0,21 & 0,75 \\
\hline average & 1.57 & 0.91 & 0.81 & 0.95 & 1.12 & 0.31 & 0.63 \\
\hline $\mathrm{SD}$ & 0.84 & 0.40 & 0.43 & 0.49 & 0.51 & 0.16 & 0.20 \\
\hline \multicolumn{8}{|l|}{1995} \\
\hline $3 / \mathrm{fev}$ & 0.34 & 0.14 & 0,26 & 0.26 & $<\mathrm{DI}$ & $<\mathrm{Dl}$ & 0.10 \\
\hline $8 / \mathrm{fev}$ & 0.14 & $<\mathrm{DI}$ & $<\mathrm{DI}$ & $<\mathrm{DI}$ & 0.10 & $<\mathrm{Dl}$ & $<\mathrm{DI}$ \\
\hline $15 / \mathrm{ev}$ & 0.13 & 0,10 & 0.06 & 0.10 & $<\mathrm{DI}$ & 0.11 & 0.10 \\
\hline $16 / \mathrm{ev}$ & 0.08 & $<\mathrm{DI}$ & 0.08 & $<\mathrm{DI}$ & $<\mathrm{DI}$ & $<\mathrm{D})$ & $<\mathrm{Dl}$ \\
\hline $2 / \mathrm{mar}$ & 0,21 & $<\mathrm{DL}$ & 0.43 & $<\mathrm{DL}$ & 0.10 & $<\mathrm{DL}$ & $<\mathrm{Dl}$ \\
\hline average & 0.18 & 0.09 & 0.18 & 0.11 & 0.08 & 0.08 & 0.08 \\
\hline $\mathrm{SD}$ & 0.10 & 0.03 & 0.16 & 0.08 & 0,02 & 0,02 & 0,02 \\
\hline \multicolumn{8}{|l|}{1996} \\
\hline $12 / \mathrm{ecv}$ & 1.28 & 0,28 & 0.86 & 0.52 & 0.12 & 0,22 & 0.34 \\
\hline $15 / \mathrm{fev}$ & 0.13 & 0.14 & 0.12 & 1.35 & 0.48 & 0.47 & 0.46 \\
\hline $21 / f \mathrm{ev}$ & 0.23 & 0.09 & 0.19 & 0.37 & $<\mathrm{Dl}$ & 0.11 & 0.14 \\
\hline $23 / \mathrm{fev}$ & 0.16 & $<\mathrm{DI}$ & $<\mathrm{DI}$ & 0.20 & 0,22 & 0.11 & 0.21 \\
\hline $26 / \mathrm{fev}$ & 0.13 & 0.10 & $<\mathrm{DI}$ & $<\mathrm{Dl}$ & $<\mathrm{DI}$ & $\angle \mathrm{DL}$ & $<\mathrm{DL}$ \\
\hline average & 0.39 & 0,14 & 0.26 & 0.50 & 0,19 & 0.20 & 0,24 \\
\hline $\mathrm{SD}$ & 0.50 & 0.08 & 0.34 & 0.50 & 0.17 & 0.16 & 0.16 \\
\hline \multicolumn{8}{|l|}{1997} \\
\hline 27/jan & 1.28 & 1,14 & 1.18 & 0.81 & 0,28 & 0.36 & 0.30 \\
\hline $4 / \mathrm{fev}$ & 0.99 & 0,51 & 0.38 & $<\mathrm{DI}$ & 0.66 & $<\mathrm{DI}$ & $<\mathrm{DI}$ \\
\hline $13 / \mathrm{fev}$ & 1,17 & 0,35 & 0,73 & 1.48 & 1.37 & 0.96 & 0.28 \\
\hline $15 / \mathrm{ev}$ & 2,01 & 1,48 & $<\mathrm{DH}$ & 0.31 & 0.17 & 0,96 & 2.08 \\
\hline $20 / \mathrm{fev}$ & 0.49 & 0,56 & .0 .20 & 0,08 & $<\mathrm{DI}$ & 0.87 & 0.61 \\
\hline average & 1.19 & 0.81 & 0.51 & 0.55 & 0.51 & 0,64 & 0.67 \\
\hline $\mathrm{SD}$ & 0.55 & 0.48 & 0,45 & 0.60 & 0.53 & 0.40 & 0.81 \\
\hline
\end{tabular}

$\angle \mathrm{DI},=$ below detection limit 
compared to marine environments seriously affected by oil where the concentrations are circa of 500 $\mu g . \mathrm{L}^{-1}$ (El-Samra et al., 1986; Lara et al., 1995). According to Law (1981) concentrations of $5 \mu \mathrm{g} . \mathrm{L}^{-1}$ are considered low for inshore areas when using spectrofluorimetric method. During the sampling period all stations had concentrations lower than 5 Hg. $\mathrm{L}^{-1}$, so based on Law's assumption (1981), the area can be considered unpolluted. Reported DDPHs in the vicinity of other Antarctic research stations (Cripps, 1992) are comparable with our results. The origin of the DDPHs in these surface waters cannot be established precisely using only fluorescence techniques because the limitations of the method. However it was possible to see a trend among the sampling stations during the different years.

In the summer of 1994 we found the highest average concentration compared to the other years studied, except for stations \#6 and \#7. This result was confirmed by the statistical analyses between the DDPHs concentrations and the sampling period, which showed a positive correlation $(58 \%)$ only for samples of 1994. According to the main circulation pattern of Admiralty Bay proposed by Pruszak (1980), stations $\# 6$ and $\# 7$ are located in an area far away from the influence of Ferraz and Arctowski Stations. Sampling sites $\# 1$ and $\# 8$ very often showed the highest average concentrations when comparing all sites for individual years. These stations are located in front of the Polish (Arctowski, $\# 1$ ) and the Brazilian (Comandante Ferraz, $\$ 8$ ) Research Stations, which are areas with intense boating activities and constant diesel fuel uses. The statistical analysis showed a positive and significant correlation $(>90 \%)$ of DDPHs and the distance from the Ferraz and Arctowski research stations, suggesting them as the most important sources of DDPHs to that environment. According to Pruszak (1980) and Bícego et al. (1996), the surface currents, which are mainly forced by winds, penetrate the Bay through stations $\# 3$ and $\# 6$, move towards the stations $\# 7$ and $\# 8$, exiting the bay through station \#5. For the first year of study Station $\$ 5$ presented relatively high concentrations probably because the action of currents in this area, which bring oil hydrocarbons from Ferraz Station. During the summer of 1997, the contribution of Ferraz Station on station $\# 7$ could be observed. On February $13^{\text {th }}$ a higher concentration of DDPHs (2.04 $\left.\mu \mathrm{g} . \mathrm{L}^{-1}\right)$ was verified in station $\# 8$ and two days later, February 15 , the station $\$ 7$ had its concentration increased from 0.28 to $2.08 \mu \mathrm{g} . \mathrm{L}^{-1}$. These results suggest that the current may transport the oil from Ferraz to several areas in the Bay within a short period of time. The contamination observed could also be a result from the anchorage of visiting ships around station \#7. From all period studied, the greatest values for stations $\# 6$ and $\# 7$ occurred during the summer of 1997. During the summer of 1995 DDPHs concentrations were the lowest observed. In 1997, the average concentration increased again and the highest levels were once more in the stations \#1 and $\$ \mathbf{8}$.

A study of DDPHs in the South West Atlantic and Southern Ocean between 30 and $60^{\circ} \mathrm{S}$ showed an average concentration of $0.31 \mu \mathrm{g} . \mathrm{L}^{-1}$ oil equivalents for the oceanic samples and it was proposed as the baseline value for the area (Bícego et al., 2002). In this study the sites collected in 1994 and 1997 had average concentrations equal or higher than this suggested baseline. The average concentration ranged from 0.31 to $1.57 \mu \mathrm{g} . \mathrm{L}^{-1}$ in 1994 , and from 0.51 to $1.19 \mu \mathrm{g} . \mathrm{L}^{-1}$ in 1997. Even though these concentrations were higher than the suggested baseline, they are still considered low. During the summer of 1995 and 1996 the average for each station ranged from 0.08 to $0.50 \mu \mathrm{g} . \mathrm{L}^{-1}$, with $81 \%$ of these samples below $0.31 \mu \mathrm{g} . \mathrm{L}^{-1}$. During these two summers the whole area was considered as unaffected by oil pollution.

\section{Conclusions}

Slight dissolved/dispersed petroleum hydrocarbon contamination was observed during the 4-year survey. Even though the concentrations were in general low, the areas surrounding Research Stations Arctowski (\#1) and Comandante Ferraz (\#8) showed the highest concentrations indicating a consistent contribution from these two Stations. The influence of the station $\# 8$ over the adjacent areas ( $\$ 5$ and $\# 7$ ) was also observed. Summers of 1995 and 1996 had the lowest concentrations of dissolved/dispersed petroleum hydrocarbons and results can be compared to the baseline values for South West Atlantic and Southern Ocean. Summers of 1994 and 1997 had higher concentrations than open ocean waters but they are still considered low.

\section{Acknowledgemens}

The authors gratefully acknowledge support of this work by CIRM/PROANTAR/CNPq. The authors thank Dra. Rosane G. Ito and Lourival P. Souza for field and laboratory help and the crew of the Comandante Ferraz Brazilian Station, and to M.Sc. Luciana Frazão for the statistical analysis.

\section{References}

Bícego, M. C.; Weber, R. R. \& Ito, R. G. 1996 Aromatic hydrocarbons on surface waters of Admiralty Bay, King George Island, Antarctica. Mar. Pollut. Bull., 32(7):549-553. 
Bícego, M. C.; Zanardi-Lamardo, E.; Taniguchi, S. \& Weber, R. R. 2002. Natural levels on dissolved dispersed aromatic hydrocarbons in South West Atlantic and Southern Ocean. Mar. Pollut. Bull., 44(10): $1166-1169$.

COMNAP - Council of Managers of National www.comnap.aq.

Cripps, G. C. 1992. Baseline levels of hydrocarbons in seawater of the Southern Ocean: Natural variability and regional patterns. Mar. Pollut. Bull., 24(2):109-114.

Cripps, G. C. \& Shears, J. 1997. The fate in the marine environment of a minor diesel fuel spill from Antarctic research station. Environ. Monit. Assessment, 46:221-232.

Ehrhardt, M. 1983. Determination of dissolved/dispersed hydrocarbons In: Grassholf, K.; Ehrhardt, M. \& Kremling, K. $2^{\text {nd }}$ ed. Methods of seawater analysis. Weinhem, Verlag Chemie, p.281-290.

Ehrhardt, M. \& Knap, A. 1989. A direct comparison of UV fluorescence and GC/MS data of lipophilic open-ocean seawater extracts. Mar. Chem., 26:179-188

Ehrhardt, M. G.; Burns, K. A. \& Bícego, M. C. 1992 Sunlight induced compositional alterations in the seawater soluble fraction of crude oil. Mar. Chem., 37:53-64.

El-Samra, M. I.; Emara, H. I. \& Shunbo, E. 1986. Dissolved petroleum hydrocarbon in the northwestern Arabian Gulf. Mar. Pollut. Bull., 17(2):65-68.

Gauthier, T. D.; Shane, E. C.; Guerin, W. F.; Seitz, W. R. \& Grant, C. L. 1986. Fluorescence quenching method for determining equilibrium constants for polycyclic aromatic hydrocarbons binding to dissolved humic materials. Environ. Sci. Technol., 20(11):1162-1166.

Green, G. \& Nichols, P. D. 1995. IIydrocarbons and sterol in marine sediments and soils at Davis Station, Antarctic: a survey for human derived contaminants. Antarct. Sci., 7(2):137-144.

IOC/UNEP. International Oceanographic Commission/United Nations Environment Program. 1984. Manual for monitoring oil and dissolved/dispersed petroleum hydrocarbons in marine waters and on beaches. Manual and guides. $13 p$.
Kennicutt, M. C.; Sweet, S. T.; Fraser, W. R.; Stockton, W. L. \& Culver, M. 1991.The grounding of Baia Paraiso, Artur Harbour, Antarctica 1. Distribuition and fate of oil spill related hydrocarbons. Environ. Sci. Technol., 25(3):509-518.

Lara, R. J.; Asteasuain, A.; Rusansky, C. \& Asteasuain, R. 1995. Distribution of petroleum liydrocarbons in waters of the Bahia Blanca Bay, Argentina. Mar. Pollut. Bull., 30(4):281-283.

Law, R. J. 1981. Hydrocarbon concentrations in water and sediments from U.K. marine waters determined by fluorescence spectroscopy. Mar. Pollut. Bull., 12(5):153-157.

Law, R. J.; Marchand, M.; Dahlmann, G. \& Fileman, T. W. 1987. Results of two bilateral comparisons of determination of hydrocarbon concentration in coastal seawater by fluorescence spectroscopy. Mar. Pollut. Bull., 18(9):486-489.

Lenihan, H. S. 1992. Benthic marine pollution around McMurdo Station, Antarctica - A summary of findings. Mar. Pollut. Bull., 25(9-12):318-323.

Maher, W. A. 1983. Use of fluorscence spetroscopy for monitoring petroleum hydrocarbon contamination in estuarine and ocean waters. Bull. environ. Contamin. Toxicol., 30:413-419.

Parlanti, E.; Wörz, K.; Geoffroy, L. \& Lamotte, M. 2000. Dissolved organic matter fluorescence spectroscopy as a tool to estimate biological activity in a coastal zone submitted to anthropogenic inputs. Org. Geochem., 31:17651781 .

Pruszak, Z. 1980. Currents circulation of water of Admiralty Bay (region of Arctowiski Station on King George Island). Polish Polar Res., 1:55-74. 